Vol. XXIII No $2 \quad 2017$

\title{
ASPECTS OF COMPATIBILITY AND CONVERGENCE OF THE ACCOUNTING INFORMATION COMPRISED IN THE BALANCE SHEET IN THE DKMT EUROREGION (DANUBE-CRIŞ-MUREŞ-TISA)
}

\author{
Andreea Mihaela MARIN*, Cristiana Daniela LAZĂR**, Ion PEREŞ** \\ * „Eftimie Murgu” University Reşiţa, Romania \\ ** The West University, Timişoara, Romania \\ andreeamarinmihaela@yahoo.com, cristianamun@yahoo.com
}

\begin{abstract}
In order to study the compatibility and convergence of accounting information between the Autonomous Region Vojvodina and the West Development Region of Romania and implicitly between Vojvodina and Hungarian counties of DKMT, it is necessary to study the compatibility and possible convergence between the Vojvodina Balance Sheet (Bilans Stanja) and the Romanian Abridged Balance Sheet. In order to reach the set goal we opted for the detailed presentation of the Bilans Stanja, with the highlighting of correspondences, indicators' manner of calculation (when necessary) and the highlight of differences and complementarities.
\end{abstract}

Keywords: abridged balance sheet, bilans stanja, accounting information, DKMT Euroregion

\section{Brief presentation of DKMT Euregion (Danube-Criș-Mureș-Tisa)}

Euroregions are cross border regions constituted on geographic and historic bases for economic necessities, especially out of the need for economic and inter-cultural cooperation among the populations and ethnic groups of the area. Up to now 80 Euroregions have been created. The first Euroregion established in 1958 was "EUREGIO" (Euregio Gronau-Enschede) at the border between Germany and the Netherlands.

The DKMT Region (Romanian DanubeCriș-Mureș-Tisa, Hungarian Duna-KörösMaros-Tisza, Serbian Dunav-Kriš-MorišTisa or Дунав-Криш-Мориш-Тиса) is a European region of cross border cooperation established in 1997, among Romania, Hungary and Serbia. The largest city is the Municipality of Timișoara.

The Euroregion DKMT (Danube-CrișMureș-Tisa) comprises counties (districts) from three countries, Romania, Serbia and
Hungary including:

- from Romania: West Development Region, with the counties Arad, CarașSeverin, Hunedoara, Timiş;

- from Serbia: The Autonomous Region of Vojvidina, with the capital in Novi Sad;

- from Hungary: the counties Bács-Kiskun, Ciongrad, Jász-Nagykun-Szolnok, Bichiș.

The DKMT Euroregion was established on the $21^{\text {st }}$ of November 1997. Since 2015, the presidency of the Euroregion has been assured by the Timiş county.

2. The annual financial situations in Vojvodina - Republic of Serbia

The annual financial situations represent documents of financial reporting indicating at a certain moment the level, size of real and monetary flows of an economic entity, originated from its relations with the exterior, namely from the internal activity [1].

These are synthesis documents "supplying information about the entity's functional position, results and changes of financial 
position" [2].

According another opinion [3], financial situations are regarded as "a comprehensive image of wealth, expressing the entity's financial position in monetary units by the correlation between economic assets, financing sources and results obtained at the end of the accounting period", or financial situations are considered to be the documents providing information about the faithful image of the financial position, performance, change of financial position, changes in capital and equity, useful for a wide sphere of users enabling them to make their economic decision [4].

In order to observe and analyse the Vojvodina financial situations we made appeal to the economic entities and institutions in the area, making efforts to observe the legal provisions in force in the neighbouring country.

It is impossible to obtain actual information with economic character, not even related to private economic entities from Serbia, as the legislation in force forbids and punishes the circulation of any piece of information of this sort across the frontier. In this context, following repeated endeavours, we have found and used three documents with public character, which constituted the object of certain Romania-Serbian cross border projects, namely:

- the financial situations of the Zrenjanin Chamber of Commerce for the year 2010;

- the financial situations of the Pančevo Chamber of Commerce for the year 2010;

- the financial situations of the Regional Agency of Social-Economic Development Banat of Zrenjanin.

The two chambers of commerce operate according to legal forms of organisation corresponding to the companies by share, and the Agency is organised as a company with limited liability (SRL).

Irrespective of the type of legal organisation and size, the economic entities with the registered headquarters in the Republic of Serbia elaborate, at the end of the financial year (31st of December) and publish in the official gazette of the state, the following annual financial situations:

- Bilans Stanja (The Balance Sheet in se);

- Bilans Uspeha (Profit and Loss Statement);

- Statistički Aneks (Statistical Annex).

The three documents above are published in Serbian and English. The economic entity has the freedom to decide their publication in traditional Serbian language, but in this they have to be accompanied by the variant in Latin-alphabet Serbian.

The publication of the Statistical Annex to the Balance Sheet (Statistički Annexes) is left to the discretion of the economic entity, but only starting with the third annex (the publication of the first two is mandatory). There are 11 annexes to the balance sheet, with a multitude of items of information, many of them revealing indicators from the Bilans Stanja and Bilans Uspeha or being control information, the main annexes to the balance sheet are the following:

I. general information about the legal person and entrepreneurship;

II. substantial changes in material investments and state of technology and equipment, as well as live stock;

III. structure of capitals;

IV. structure of immobilisations;

V. structure of stocks and liabilities;

VI. receivables and debts to cash;

VII. expenditure and other consumptions;

VIII. other incomes.

For these considerations and especially due to the fact that many items of information from Bilans Stanja and Bilans Uspeha are repeated in Statistički Aneks, the present article considers that, in order to study the compatibility and convergence of accounting information between the Autonomous Region Vojvodina and West Development Region of Romania and implicitly between Vojvodina and the Hungarian counties composing the DKMT, it is necessary to study the compatibility and possible convergence between the Balance Sheet of Vojvodina (Bilans Stanja) and the Abridged Balance Sheet of Romania. 
3. Analysis of compatibility and convergence between the Bilans Stanja and the Abridged Balance Sheet

The Balance Sheet, as component of financial situations, renders the equity (own capitals) by the difference between assets and liabilities, provides information about the nature and amounts invested in the resources of economic entities, its obligations towards creditors, as well as the shares of owners in these resources, being considered "the main instrument by which one achieves the application of the accounting principle of double representation of patrimonial items" [1].

The Bilans Stanja is divided, like the Romanian balance sheet (and the European balance sheet) into two large chapters:

- Assets (Aktiva);

- Liabilities (Pasiva).

The assets of Bilans Stanja is made of:

A. Immobilised assets (line 001);

B. Assets from exploitation (line 012);

C. Depreciations of equity (line 023 ).

At the end of the chapter one highlights separately:

E. The extra-balance assets.

The detailed presentation of the calculation of assets elements is the following:

A. The immobilised assets have a correspondent in the abridged balance sheet in line 04, Form F10 and are calculated from:

I. Subscribed and unpaid equity (line 002 with direct correspondent in F10, line 31);

II. Customers (line 003, without direct correspondent in F10, but deductible from F10, 06 of the „Customer” account);

III. Non-corporal investments (intangible, line 004, with correspondent in F10, 07);

IV. Lands, plantations, equipment and biological substances line 005, without equivalent in F10, but deductible from the afferent accounts afferent;

V. Long-term financial investments on (line 009, with correspondent in F10, line 16, but not directly).

The calculation formula is: $\mathbf{A}=\mathbf{I}+\mathbf{I I}+$ III + IV + V.
As a principle, the Bilans Stanja goes only to the details level, which makes it extremely clear and intelligible; in the given situation, on the second level of detailing we find:

IV. Lands, plantations, equipment and biological substances (with partial correspondent in F10, line 02) made of:

1. Lands, plantations (line 006, with equivalent in F10, line 02 , the afferent account);

2. Equipment (line 007, idem);

3. Biologic substances (line 008, idem).

V. Long-term financial investments, made of:

1. Shares or equity contributions, without direct equivalent in F10, deductible from the accounts;

2. Other long-term financial investments (idem).

B. The exploitation assets (line 012, without direct correspondent in F10, and they can be recreated from F10 circulating assets):

I. Reserves (line 013, with correspondent in F10, line 013);

II. Fixed assets for sale and assets from assignments (line 014, without correspondent in F10);

III. Short-term receivables, investments and cash (line 015, with partial correspondent in F10, lines 06, 07, 08);

IV. Assets related to delayed income tax (line 021, without correspondent in F10).

The calculation formula is: $\mathbf{B}=\mathbf{I}+\mathbf{I I}+$ III + IV.

On the second detailing level:

III. Short-term receivables, investments and cash have the following components:

1. Receivables (line 016, with equivalent in F10, 06);

2. Receivables on taxes on incomes paid in excess (line 17, without correspondent in F10);

3. Short-term financial investments (line 18, with correspondent in F10, line 07);

4. Cash and cash equivalents (line 019, with correspondent in F10, line 08);

5. VAT, advance and delayed expenditure 
(line 020, with correspondent partial in F10, line $10,11,12$ ).

The immobilised assets, together with the assets from exploitation, form together the wealth (equity) from exploitation of the entity (line 022); they are completed by the accounting index "equity depreciations" (line 023, with indirect correspondent in Romanian accounting, in the chapter "amortisation" from annexes to the balance sheet, line 024, with correspondent with the same title in F10, line 49).

The accounting information "extra-balance sheet assets" (line 025) has a partial correspondent in F10, line 18 "incomes in advance".

The liabilities (Pasiva) from the Bilans Stanja have two components:

A. Equity (line 101, with correspondent in F10, line 29);

B. Long-terms debts and reserves (line 111, with direct correspondent in F10, line 16).

Remark: unlike the Abridged Balance Sheet which in the liabilities section starts with the debts and continues with equity, in Bilans Stanja the two indicators are presented in reversed order.

A. Equity is made of:

I. Basic capital (line 102, corresponding to F10, line 30 "Subscribed and paid-up Equity");

II. Subscribed and unpaid Equity (line 103, with correspondent in F10, line 31);

III. Reserves (line 104) with correspondent in F10, line 37);

IV. Revaluations (line 105, with correspondent in F10, line 36);

$\mathrm{V}$. Gains not achieved based on stock value (line 106, with correspondent in F10, line 39);

VI. Losses not achieved based on stock value (line 107 with correspondent in F10, line 40);

VII. Undistributed profit (line 108, equivalent to F10, line 41);

VIII. Losses (line 109, equivalent to F10, line 42);
IX. Purchases of equity shares (line 110, without equivalent in F10).

The calculation formula for equity is: $A$ $=\mathbf{I}+\mathbf{I I}+\mathbf{I I I}+\mathbf{I V}+\mathbf{V}-\mathbf{V I}+\mathbf{V I I}$.

Remarks: the equity structure in the Bilans Stanja is almost identical with the structure in the Abridged Balance Sheet.

B. The long-term debts and reserves are made of:

I. Long-term reserves (line 112, without correspondent in F10);

II. Long-term debts (line 113, with equivalent in F10, line 16);

III. Short-term debts (line 116, with equivalent in F10, line 13);

IV. Delayed debts (line 123, without correspondent in F10).

The calculation formula for B. Long term debts and reserves is:

\section{B = IX (line 110) + I + II + III.}

Total debts (line 124, without equivalent in F10, but easy to calculate from the sum of lines 13 and 16) are calculated with the formula:

Total debts $=\mathrm{B}+\mathrm{IV}$.

Total liabilities will be the result of the sum of indicators Equity + Total debts. In the Liabilities section there are also highlighted extra-balance sheet debts (line 125, without equivalent or correspondent in F10).

Remark: the structure of liabilities in the Bilans Stanja is much closer to the structure of liabilities in the Abridged Balance Sheet than the structure of assets to the afferent chapter in our financial situation.

\section{Conclusions}

The document Bilans Stanja and the Abridged Balance Sheet contain, in substantial proportion, accounting information with the same content, but different as regards the organisation structure of forms, mainly in the assets section; the assurance of the two financial situations convergence is easy and involves a minimum effort of adaptation, including of the accounts plans. 


\section{References}

[1] Matiş D., Pop A., Financial accounting (in original in Romanian), Cluj-Napoca, Casa cărţii de Ştiinţă Press, 2010.

[2] Ristea M., Dumitru C.G., Ionaș C., Irimescu A., Accounting of commercial companies (in original in Romanian), vol. I, Bucharest University Press, 2009.

[3] Mateș D., Pereș I., Pereș C., Basics of accountancy (in original in Romanian), Timişoara, Mirton Press., 2005.

[4] Paraschivescu M.D., Radu F., Management of financial accountancy (in original in Romanian) Iaşi, Tehno. Press., 2008.

[5] Law 82/1991, Law of Accountancy, with further alterations and completions, updated.

[6] Order of the Minister of Public Finances no. 1802/2014 for the approval of the Accounting Regulations regarding the individual annual financial situations and the consolidated annual financial situations, updated.

[7] https://ro.wikipedia.org/wiki/Euroregiunea_DKMT. 